\title{
2018年7月西日本豪雨における 潮汐起因の河川背水に関する解析と現地調査
}

\author{
高木 泰士 $1 \cdot$ Luc HENRY $^{2}$ ・水落 拓海 3 \\ 1正会員 東京工業大学准教授 環境・社会理工学院（干152-8550 東京都目黒区大岡山2-12-1） \\ E-mail: takagi@ide.titech.ac.jp \\ 2東京工業大学 環境・社会理工学院修士課程（†152-8550 東京都目黒区大岡山2-12-1） \\ E-mail: henry.1.aa@m.titech.ac.jp \\ 3 東京工業大学 工学部国際開発工学科学士課程（干152-8550 東京都目黒区大岡山2-12-1） \\ E-mail: mizuochi.t.aa@m.titech.ac.jp
}

\begin{abstract}
合敷市真備町では西日本豪雨で堤防が決壞し，約2100世帯が全壞した。被害拡大の一因として本支川合 流部の背水による水位上昇が指摘されている。一方, 高梁川河口は河川改修や臨海開発で川幅が著しく広 がっており, 瀬戸内海でも日潮差が特に大きい場所に位置するため, 潮汐が河川水位に影響した可能性も 無視できない，本研究では，洪水時に感潮域が潮止堰の上流側に延伸寸る可能性や，2018年豪雨で河川水 位上昇と上げ潮の時間帯が一致していたことなど，潮汐の影響を各種解析で示した．また，高梁川沿いに

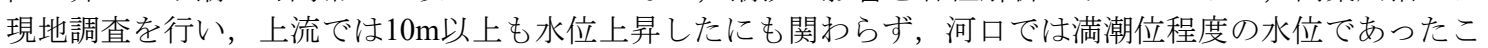
とを明らかにした，以上より，潮汐と河川水位の関係性を考察し，洪水に及ぼす海からの影響について指 摘した.
\end{abstract}

Key Words : 2018 Western Japan Flood, tide, backwater, submerged weir, field survey, numerical model

\section{1. はじめに}

2018年6月28日から7月8日にかけて前線や台風7号の影 響により，日本付近に暖かく非常に湿った空気が供給さ れ続け，西日本を中心に全国的に広い範囲で記録的な大 雨となった1). 広島, 岡山, 愛媛など多くの県で河川の 汇濫や洪水，土砂災害が発生し，死者 224 人，行方不明 者8人 (2018年11月6日時点) を出し，豪雨災害としては 平成最悪の被害となった2).このうち岡山県における死 者・行方不明者は64人である. 特に，倉敷市真備町で被 害が大きく，国土地理院の調べによると，堤防の決壊の ため市街地の約 3 割が浸水し, 最大浸水深は $4.8 \mathrm{~m} に$ に達し ている.

真備町は，岡山県西北部から水島灘につながる高梁川 と広島県東北部より岡山県西部へと流れる小田川が合流 する場所に位置している. 2つの河川に囲まれて, 過去 にもしばしば洪水被害に見舞われてきた。特に，1893年 10 月の洪水では高梁川本川が決壊し，溺死者 68 人，浸水 家屋が776戸に上った ${ }^{3)}$. その後，高梁川本川の河川改修 が進み，本川の破堤は見られなくなったが，1972年と 1976年には小田川下流が決壊して, 真備町で大規模な浸
水が発生している，その後, 河道整備や排水機場が設置 されるなど対策が進められているものの, 抜本的な解決 には至らず，今次の災害につながっている.

今回の豪雨災害では, 真備町の堤防破堤・洪水とバッ クウォーター (背水現象) の関係性が, 災害直後よりマ スメディアによって指摘されている4,5)。この現象は, 本川である高梁川の水位が著しく高いため，支川の小田 川からの流入が阻害されて合流部で水位が上昇寸るため に生じる. このリスクは以前より認識されており，2017 年には国土交通省が高梁川水系河川整備計画多を策定 し，背水影響を軽減する目的で合流点の付替えを計画し ている.

これに対して, 高梁川流域の洪水原因について海の視 点からの問題指摘はこれまでのところない．潮汐の河川 への影響は, 海域静水面の延長と河床の交点より上流で は微弱であるといわれている8. 高梁川と小田川の合流 地点は河口から $13 \mathrm{~km} ほ と ゙$ 離れており, 平均河床高も約 T.P. $+7 \mathrm{~m}^{0,7)}$ と十分に高い. このため, 今回の豪雨でも潮 汐自体が波として直接上流へと伝わり洪水の主原因にな ったとは考えにくい. しかし, 潮汐が河口部のせき上げ 背水や出水の阻害を誘発し, 間接的に上流の水位変化に 
影響を与えた可能性は否定できない. 本研究では, 各種 の解析と現地調查に基づいて，2018年7月西日本豪雨時 の高梁川の潮汐と河川水位の関係について検討する.

\section{2. 河口地理 $\cdot$ 潮位 $\cdot$ 水文条件}

ここでは，潮汐の河川への影響を検討する上で特に重 要な河口の地理, 潮位, 水文条件について述べる.

\section{（1）河口地理}

高梁川は明治時代には現在の小田川合流地点より上流 で東西に分流し，西高梁川，東高梁川として別々に水島 灘につながっていた（図-1a）。その後大正年間に行わ れた高梁川改修工事で，天井川であった東高梁川を締め 切って廃川化し，同時に西高梁川（現高梁川）の川幅が 拡幅された9)。さらに河口周辺では，1953年からの水島 臨海工業地帯の開発で港湾や工業用地が造成され，火力 発電所，製鉄所，石油精製工場，化学工場が次々に建設 された.この一連の開発で高梁川の中洲がなくなり河口 域が大きく広がっており（図-1b），河口部東側は高梁 川航路，西側は玉島東航路のため, 水深もかつてより深 くなっている. 河口を横断する水島大橋付近では, かつ ては200m程度であった川幅が現在では1.1kmと5倍以上に 広がっている。このように河口部が広がることで，海水 の流入も増えて，海の河川への影響がより強まっている

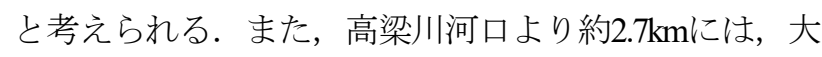
正末期に潮止堰が建設されており，現在その上流で農業 用水の取水が行われている. 後で述べるように潮汐の上 流への影響を考える際には，この潮止堰の洪水時の水理 条件が重要となる.

\section{(2) 潮位条件}

高梁川河口には乙島に検潮所があるが，過去の潮位デ 一タがインターネット上で公開されていない．また，後 で述べるように，本研究では上げ潮と下げ潮の区別を天 文潮位よりおおまかに判断している。 そこで観測潮位の 代わりに沿岸域流体モデルDelft3D FLOWを利用して2018 年豪雨時の天文潮位を推算した。 このモデルでは2次元， 3次元の解析を行うことができるが，本検討では2次元モ デルを使用した．これは津波や高潮の解析で一般的に用 いられる非線形長波方程式モデルと同等であり，広範囲 な潮汐の解析に適している ${ }^{10}$. 時間積分にはADI法, 移 流項の空間差分にはCyclic 法を使用した. 計算タイムス テップは0.2分とし，瀬戸内海全域を含む図-2aの範囲を 約 $1 \mathrm{~km}$ 格子で再現した。 海域境界には TPXO7.1 Global Inverse Tide Model ${ }^{11)}$ より抽出した主要13分潮を入力条件とし て設定した.

予測精度を確かめるため，広島，尅（海上保安庁が観 測・公開） と宇野（気象庁）の潮位データを解析結果と 比較した（図-2b）。豪雨による災害が各所で発生した7 月6日から7日にかけてのデータのため久測の箇所もある

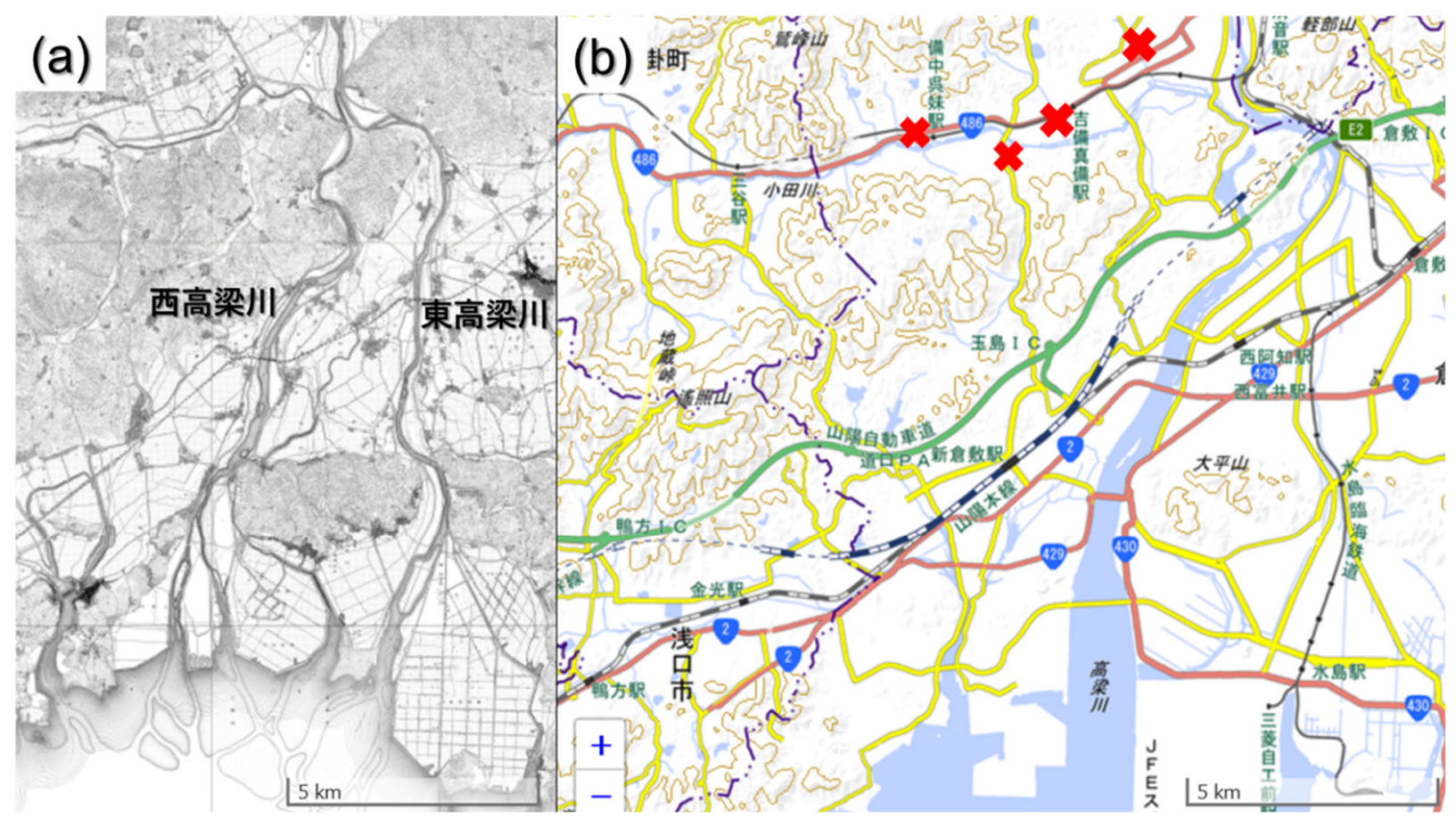

図-1 高梁川河口周辺および小田川下流域：(a) 明治期 1897年測図（今昔マップより）， (b) 現在. 赤色の×印は現地報道 5 ) に基づく破堤位置の概略. 

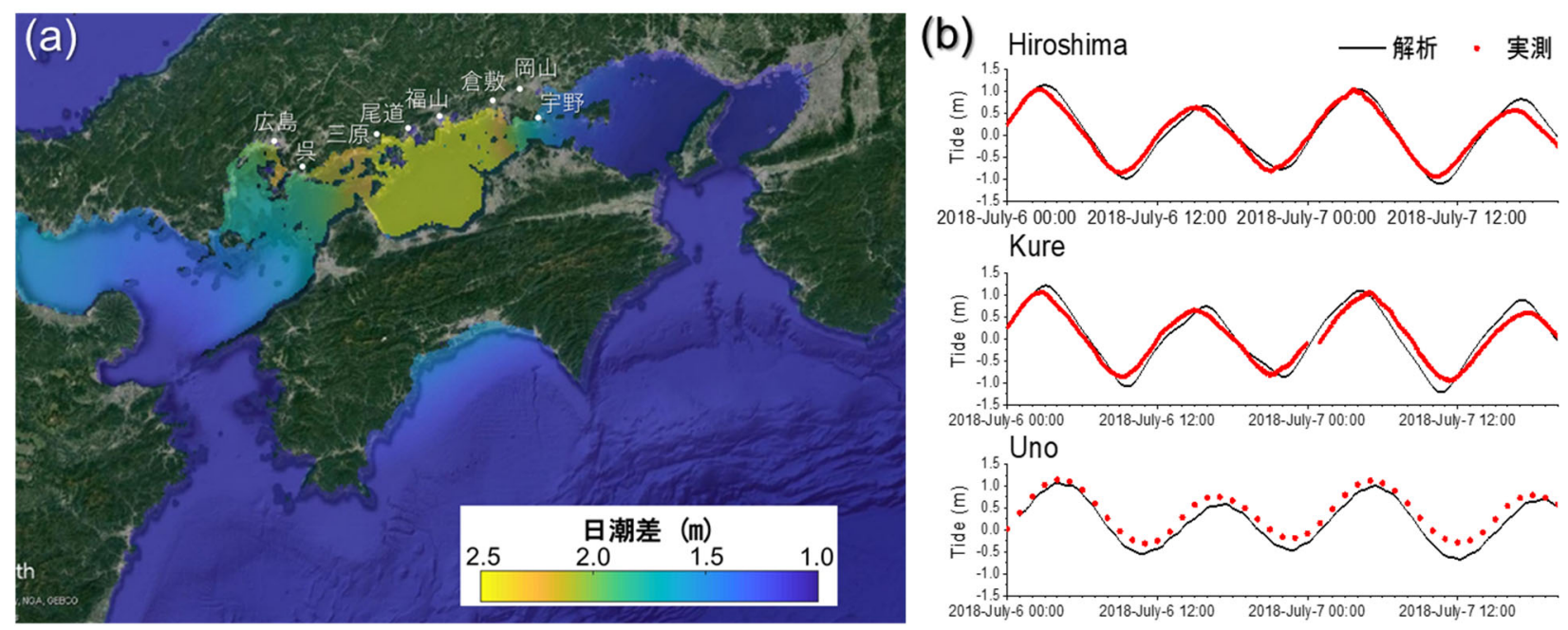

図-2 瀬戸内海の潮汐解析結果 : (a) 2018年 7月 6日の日潮差, (b) 観測潮位との比較

が，解析結果と観測值は全般的によく一致している. 特 に広島と呉はともに豪雨被災地で相当の出水があったに も関わらず，潮位変動には大きな変化を及ぼしていない， これは，上流側で大規模な洪水が起きていても，河口で は天文潮位が水位を支配し，河川下流端の強制水位条件 になるためと考えられる．この状況は後述するよう高梁 川河口でも同様と考えられる。

図-2aは解析に基づく日潮差分布図（7月6日）である が，来島海峡から備讃瀬戸の区間（呉・三原から倉敷の 範囲）で特に潮位差が大きいことがわかる。これは瀬戸 内海の両側から進行波の形で伝播寸る潮汐波がこの海域 で定常波を形成するためと考えられる. 高梁川河口もこ の海域に位置しており，瀬戸内海の中でも潮汐の影響が 大きい場所である.ただし，7月6日は小潮にあたり，図 -2は干満の差が小さいときの結果である.

\section{（3）水文条件}

岡山県は降雨量の少ない塞雨地域として知られている。 実際に日本の年間平均降雨量は1600mm程度であるが, 岡山県の降水量は $1100 \mathrm{~mm}$ 程度と顕著に少ない12)。この ため，豪雨災害リスクが比較的小さい地域とこれまで認 識されてきた。

図-3に示寸通り, 高梁川流域には最も上流地点の高梁 市に雨量（気象庁）・水位観測（国交省），小田川沿い の東三成, 高梁川沿いの日羽, 酒津, 船穂で水位観測 （国交省）が行われており，過去のデータがインターネ ット上で一般に公開されている. 最も上流に位置する高 梁における雨量が水系の全体的傾向を示寸と考えて，こ の地点の水文統計量を求めた. 図-4は水文統計ユーティ リティー13)を使用して一般化極值分布 (GEV) を42年分 （1976２017年）の年最大日降水量データに当てはめた 結果である. 今回の豪雨で記録した2018年7月6日の日降

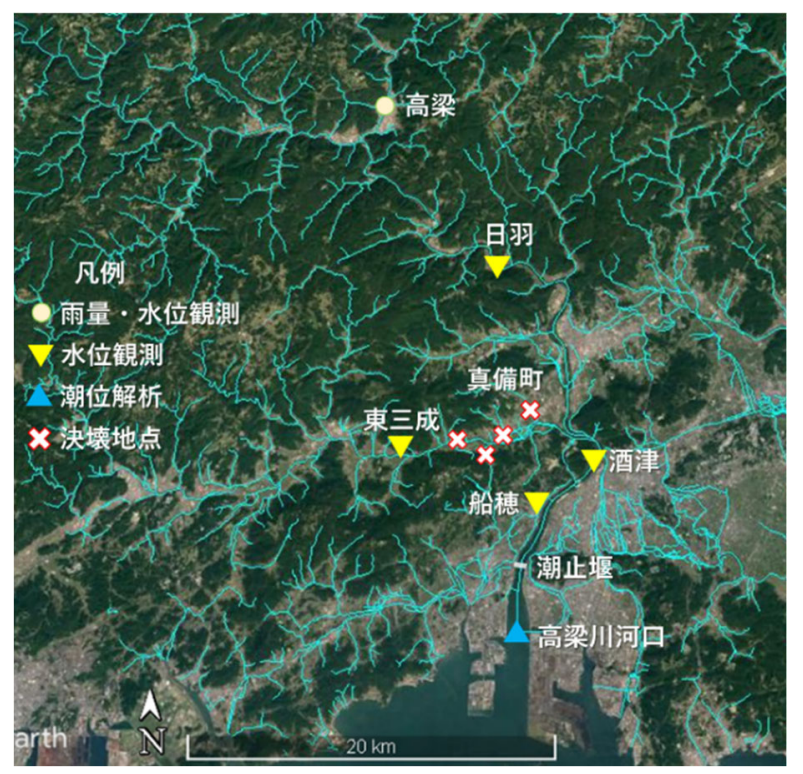

図-3 倉敷市真備町周辺の地図. Google Earthに国土数值情 報（国土地理院）より得た河川網を合成

水量174mmを暫定年最大值としてあわせて表示している.

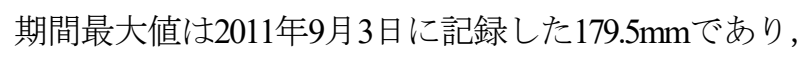
2018年7月6日はこれに次ぐ雨量である.

再現期間は各々80年, 60 年程度と推定される. 高梁川 の計画高水流量が150年に一度の降雨量を対象の》にして いることを考えると, 今回の豪雨が統計的に異常な事象 であったと直ちに判断することはできない，激甚な洪水 災害の原因は, 自然的要因ほか複眼的な視点から検証さ れるべき問題といえる.

\section{3. 河川水位分析}

図-5は2018年と2011年豪雨時の高梁川水系各地点の河 川水位であり，いずれもピーク前後の合計3日間の時系 
列を示している. 水位の高さ基準が観測所毎に異なり直 接の比較が難しいため, ここでは元の数值より豪雨開始 以前の平水時の水位を引いた值で示している. 寸なわち, 平水時からの河川水位偏差の時間推移である.

2018年豪雨では高梁の降水量に3回の明瞭なピークが 現れているが，同様に各地点とも水位のピークが3回現 れており，降雨と河川水位で強い相関が認められる。但 し，互いの出現には数時間の時差がある．例えば，小田 川との合流点に近い酒津では，7月6日0時，7月7日1時お よび11時頃に水位ピークが出現しているが，降雨ピーク はそれよりも4〜6時間早く現れている. 高梁の水位は酒 津他よりも2〜3時間ピークが早いが，高梁，日羽，酒津， 船穂の順で洪水波が上流から下流に伝わっている. 一方 で，小田川の水位を示寸東二成のデータは酒津とほぼ同

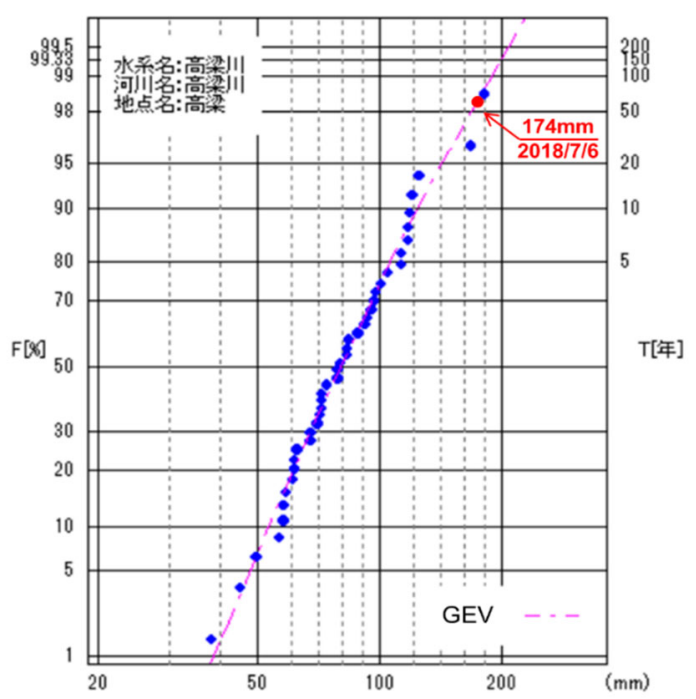

図-4 日降水量の極值統計解析結果（高梁地点）
時刻にピークを迎えており，洪水波が本流の高梁川から 支流の小田川に伝わったのか，その逆の向きなのか， 女 るいは2つの異なる洪水波であったのか，今回の分析の みでは判明しない。

図-5には，高梁川河口の潮位解析結果をあわせて示し ている。ここでは，潮位が上昇局面のときを上げ潮，下 降局面のときを下げ潮と大まかに判断して, 各々の時間 帯について色分けして示している. この判別は簡易的で, あくまで河口部付近の潮位変化を見ているのみであり, 河道内で上げ潮・下げ潮に対応する流れが実際に生じて いるか直接的には言及していない.

高梁川・小田川合流地点より下流側に位置する酒津と 船穂に着目すると，1回目と2回目の水位ピークがちょう ど上げ潮の時間帯に重なることがわかる．特に2回目の ピーク時刻に小田川支川の高馬川で決壊が確認されてい る ${ }^{14)}$. 因果関係は不明であるが，上げ潮による河川流の 流下阻害と水位上昇の間に何らかの関係性がなかったか, 今後海からの影響も含めた検証が必要と考える.

5か所の観測地点のうち, 日羽と酒津が最も水位が高 い. 日羽は山間に位置する場所で降雨が短時間に流下し たと考えられる．酒津は川幅が狭く，小田川との合流地 点の寸ぐ下流に位置しているためと考えられる. ただし 酒津の氾濫危険, 計画高の各水位はT.P.+12.00m, 12.293mであるのに対して ${ }^{15)}$ ，2018年豪雨時の最高水位は T.P.+12.35mであった．よって，図-5の酒津の水位記録は 越流が生じて頭打ちになっている可能性がある.

潮汐の影響をさらに調べるために, 高梁で最大の日降 水量を記録した2011年豪雨時の水位変化と比較寸る. こ のときも, 高梁と日羽で最初に水位が上昇し, その後酒 津, 船穂へと洪水波が伝播しており，9月3日18時頃に水

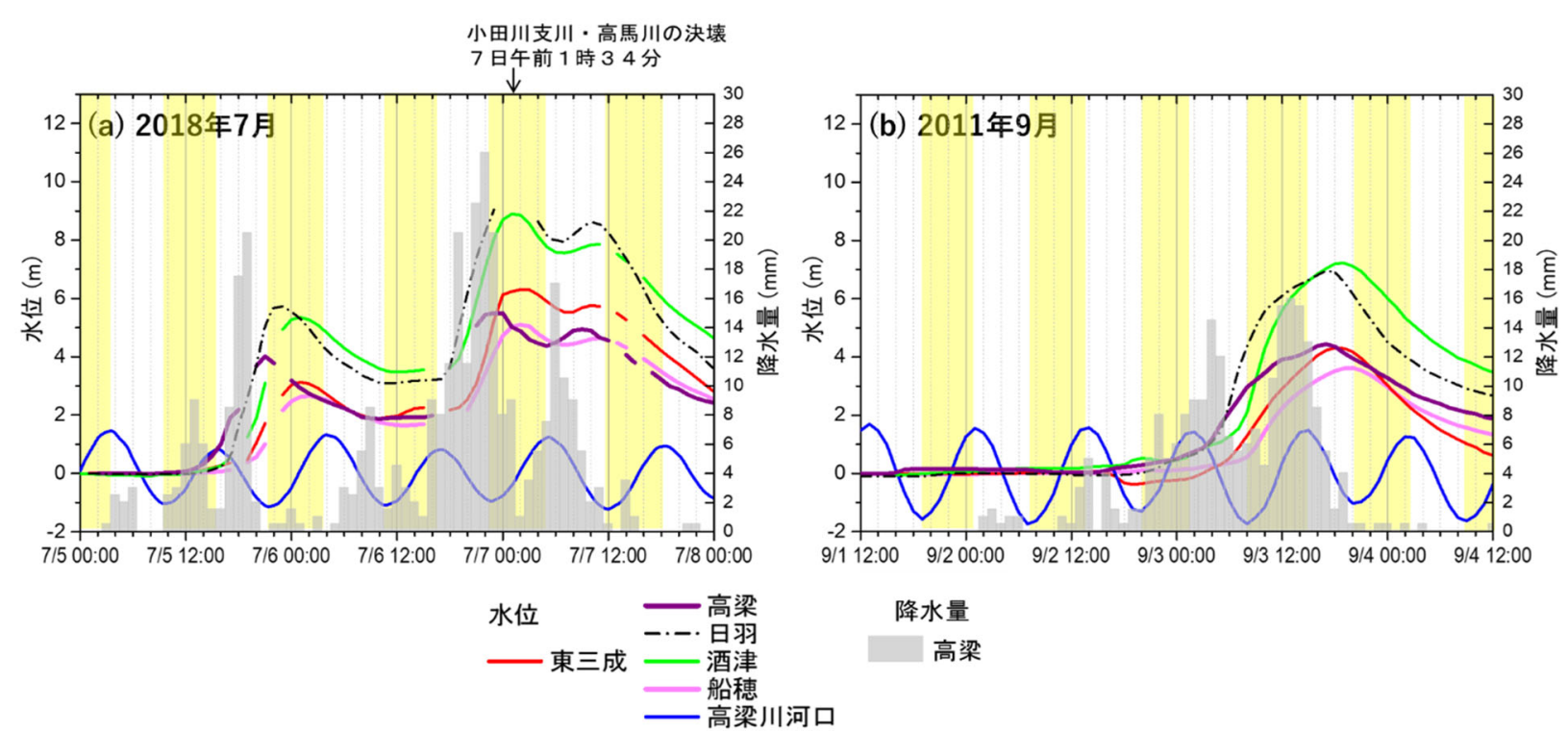

図-5 河川水位の時間推移（注 : 標高基準ではなく, 平水時の河川水位からの偏差）。高梁川河口は潮汐解析結果. (a) 2018年7月豪雨時, (b) 2011年9月豪雨時. 薄黄色の時間帯は上げ潮時, それ以外は下げ潮時を示す. 降水量は気象 庁アメダス, 水位は国土交通省水文水質データベースより取得. 
位ピークが現れている．2018年豪雨時とは異なり，この とき潮汐は下げ潮の時間帯にある。2011年9月3日の日降 水量は2018年豪雨時を上回るが，酒津のピーク水位は

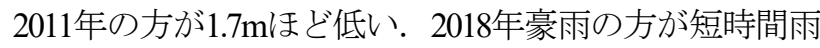
量が尖っており，このような降雨パターンが関係したと 考えられるが，2011年豪雨時は下げ潮により流下が促さ れた可能性もある.

\section{4. 高水位調査}

豪雨発生の約1か月後に現地調査を実施した。主目的 は洪水の痕跡を調べて，上流から河口までの高水位分布 を調査することである. このため, 高梁川沿いの高梁, 総社，倉敷の各市で光波測距器や測量スタッフ, GNSS 測量機器などを用いて測量を行った。水位は調査時点の 河川水面あるいは海水面からの高さである，調査は記録 的な猛暑が続いた期間で雨も降らず，河川は平水時に近 い状態であった．図-6は各地点の高水位の計測值であり， 少なくともここまでは水が上がってきたという目安であ る. 同図にはRTK-GPS測量により計測した標高值, また その測量を行っていない地点は国土地理院の5mメッシ ユ標高データの值を示している.

図-7に調査時の状況を示す，水位の到達点は，橋脚， ガードレール，階段手すり，立ち木，ネット，堤防等に 引っかかかった流木・枝葉・ゴミ（図-7a, b, e, f, g, h, i, k），空ガラスの破損（c），建物壁に付着した泥土 （d）, コンクリート護岸の変色（j, k）より判断した.

図-5aの水位データからもわかるように，2018年豪雨時， 高梁川では複数回高水位のピークが出現している. 現地 調査でも地点 jで2つのピークを確認したが，今回は高い 方の水位線を計測した。

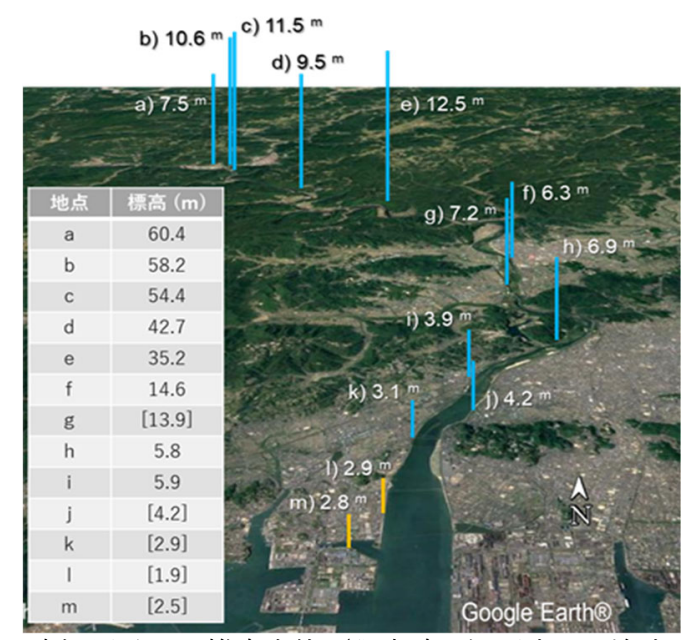

図-6 高梁川沿いの推定水位（調査時の河川水面・海水面から 測定した高さ）と計測地点の標高（カッコ内は国土地理 院基盤地図情報, それ以外はRTK-GPS測量の結果)

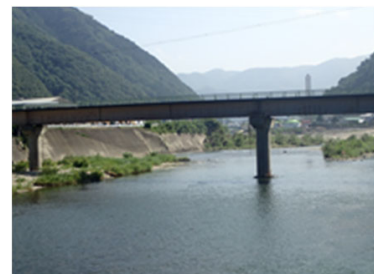

$34.775^{\circ} \mathrm{N}, 133.593^{\circ} \mathrm{E}$

(a) $2018.8 .209: 30$

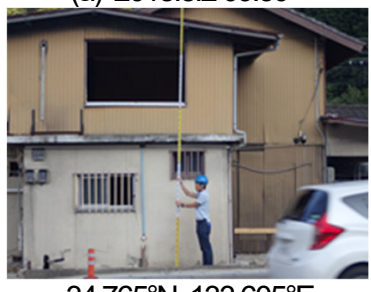

$34.765^{\circ} \mathrm{N}, 133.605^{\circ} \mathrm{E}$

(c) $2018.8 .117: 20$

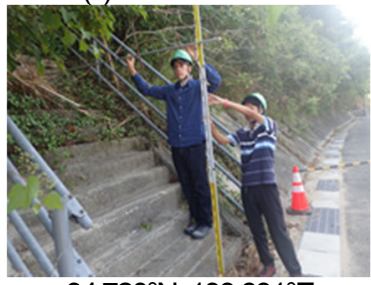

$34.720^{\circ} \mathrm{N}, 133.681^{\circ} \mathrm{E}$

(e) $2018.8 .210: 20$

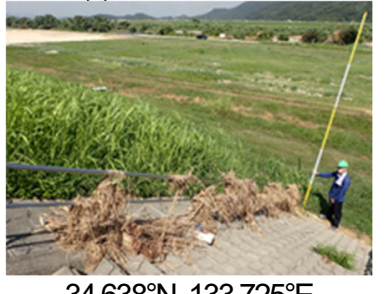

$34.638^{\circ} \mathrm{N}, 133.725^{\circ} \mathrm{E}$

(g) 2018.8.214:20

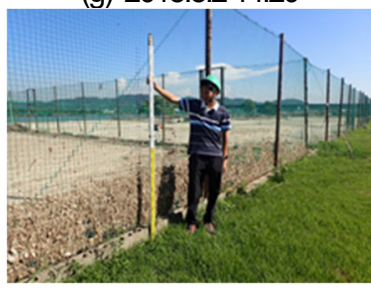

$34.582^{\circ} \mathrm{N}, 133.710^{\circ} \mathrm{E}$ (i) $2018.8 .215: 40$

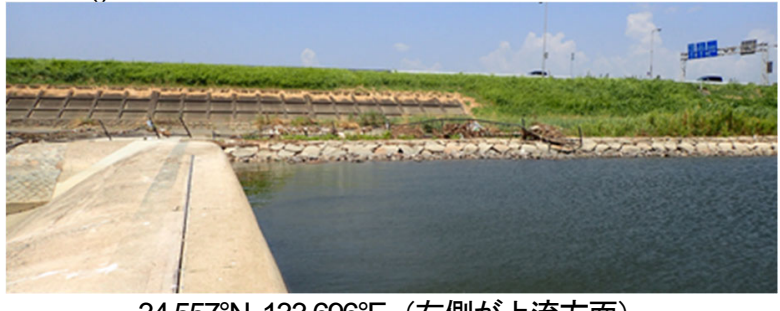

$34.557^{\circ} \mathrm{N}, 133.696^{\circ} \mathrm{E}$ （右側が上流方面） (k) 2018.8.311:10

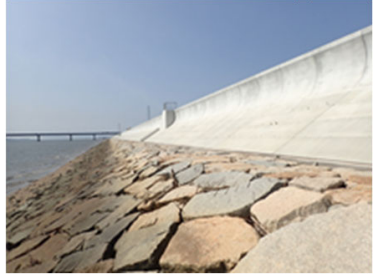

$34.533^{\circ} \mathrm{N}, 133.691^{\circ} \mathrm{E}$ (I) 2018.8.309:30

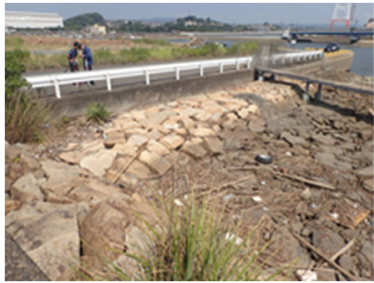

$34.523^{\circ} \mathrm{N}, 133.684^{\circ} \mathrm{E}$

(m) 2018.8.3 10:00

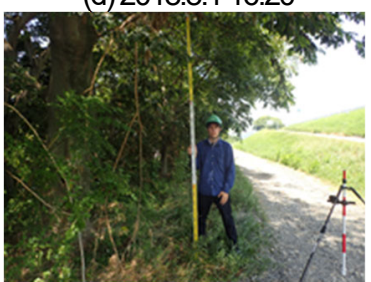

$34.663^{\circ} \mathrm{N}, 133.729^{\circ} \mathrm{E}$ (f) $2018.8 .211: 30$

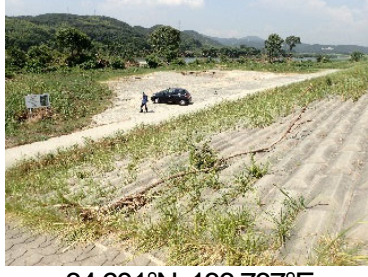

$34.601^{\circ} \mathrm{N}, 133.737^{\circ} \mathrm{E}$

(h) 2018.8.2 13:50

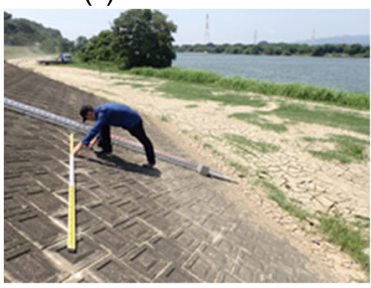

$34.568^{\circ} \mathrm{N}, 133.710^{\circ} \mathrm{E}$ (j) $2018.8 .312: 00$
図-7 現地調查で高水位の痕跡を確認した地点の状況 
地点a〜eは山間の場所で，川幅も比較的狭く，急峻 な山肌を降雨が一気に流れて，水位上昇は急激であった と推測される．竹をはじめ川岸の木々が流下方向に大き くなぎ倒されていた。 一方, 真備町に近い地点 $\mathrm{f} \sim \mathrm{h}$ は, 河川敷や中洲が広がる場所で木々が生い茂った場所が多 かったが，大規模に植生が流失しているような状況では なかった，流積も大きく，地点 $\mathrm{a} \sim \mathrm{e} に$ 比べると水位は 低く，流れも比較的緩やかであったと予想される.

地点とmは，臨海工業地帯に挟まれた河口部の状況で ある。両地点とも目立った被害はないが，満潮位程度と 考えられる高さに流木や枝木が漂着していた．現地調査 は干潮の時間帯であったため，護岸基礎が露出していた。 捨石の途中で明瞭な変色を確認したが，今回の豪雨では なく, 日々の潮位差に起因すると考えられる. 地点の 新設パラペットにも海水の上昇を示す変色はなく, 地点 $\mathrm{m}$ 周辺の道路上にも浸水の痕跡は認められなかった。よ って，この2地点は他とは異なり，洪水流起因の水位変 化は小さく, 潮汐で最高水位が決まったと考えられる. このため，先に述べたように洪水時であっても天文潮位 が河口水位を支配し, 河川下流端の強制的な境界条件に なることが裏付けられる.

\section{5. 潮汐の潮止堰遡上に関する数值解析}

高梁川河口では半日周潮の潮汐振動が卓越しているた め，上げ潮が約6時間継続する。 したがって，上げ潮の 時間と一致すると，前節で考察したよう洪水流の流下を 妨げる要因になりうる，本節ではこのような現象，すな わち潮汐起因のせき上げ背水について検討を行う。2018 年豪雨時の河川流量が不明なため，ここでは計画高水流

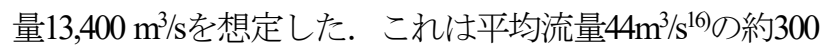
倍の猛烈な出水である. その他検討条件を表-1に示す.
本検証では，特に高梁川河口に設置されている潮止堰 に着目する. 潮止堰は落差があり, 平水時はこの部分で 射流が生じて潮汐の影響が上流に及ぶことはない．国土 交通省の河川整備計画のでも，潮止堰より下流が感潮区 間と想定されている。これに対して，図-8は潮止堰の左 岸取付部（図-7(k)の対岸にあたる）の豪雨後の状況で あり，洪水による流れは，潮止堰を大きく乗り越えてい たことを表している. 図-7(k)の地点で観察した限り， 少なくとも河川敷上で2〜3m程度の浸水が発生していた.

そこで，洪水時に潮止堰を乗り越えて潮汐の影響が上 流に及ぶことがありえるか，近年多方面で活用が進む数 值流体モデルOpenFOAMを使用して解析を行った。非圧 縮性流ソルバーのうち，interFoamを用いてVOF法に基づ く気液2相流解析を行った. 潮止堰の越流で生じる激し い乱流を再現するため, 乱流モデルにはLESを選択した. ただし，計算負荷軽減のため，断面2次元で奥行方向の 流れは無視し，潮止堰を含む $90 \mathrm{~m}$ 範囲のみ詳細に解析 した（図-9）．短距離のためこの区間の河床勾配は無視 して水平床を仮定した。 潮止堰は現地調查で測量スタッ フを用いて計測した概略值として，天端高 $2.4 \mathrm{~m}$ ，天端幅 $2 \mathrm{~m}$ の台形形状とした。 また，一部に魚道や減勢工が設 置されているが，このような付帯工は考慮していない.

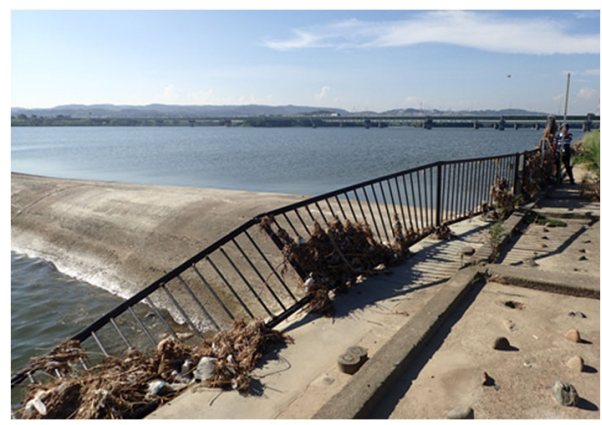

図-8＼cjkstart高梁川河口潮止堰の豪雨後の状況（右上方向が上流）

（a）計画高水流量, 潮汐考慮せず

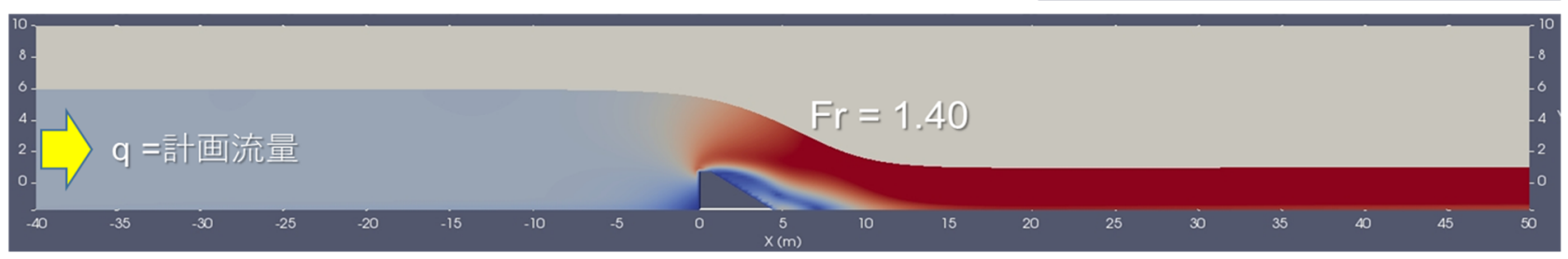

（b）計画高水流量, 潮汐 (上げ潮) 考慮

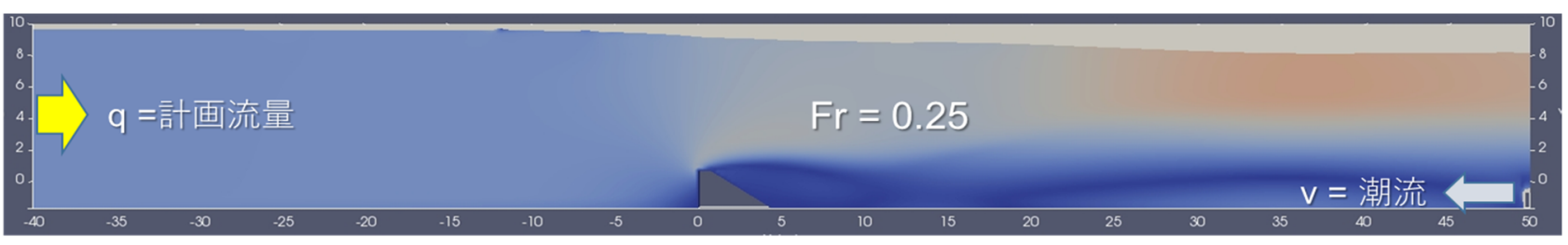

図-9 潮止堰を越える流れの数值解析. 図の左側が上流側, 右側が河口側. (a)潮流を考慮しない場合. (b)潮流を考慮. 
計算格子は $20 \mathrm{~cm} の$ 正方格子を設定し, クーラン数が 0.5を超えないよう時間ステップを逐次変化させるなど 効率化を図った．境界条件として，上流より計画高水流 量（単位幅流量 $25.8 \mathrm{~m}^{3} / \mathrm{s}$ ) を流入させて，下流から勾配 ゼロで流出させるよう設定した，さらに，潮汐の影響を 考慮するケースでは，下流境界の川底から高さ $1 \mathrm{~m} の$ 範 囲に流速流入境界を配置した。潮流なしでは計算開始か ら2分程度で流況が安定したが，潮流ありでは7分程度を 要した.

洪水時の河口は明らかに強混合型で，成層状態で流れ る訳ではないが，互いに交差する河川流と上げ潮流の両 方を厳密に再現することは難しく, 簡易的な方法として このように仮定した．上げ潮流速を想定して，流速流入 境界に $0.4 \mathrm{~m} / \mathrm{s}$ の流れを与えた。この值は，高梁川河口域 で実施された既往の観測結果17を参考にしている.

解析結果を図-9に示す．フルード数は潮止堰法尻の $5 \mathrm{~m}$ 海側（x=10m）における数值である，潮汐を考えない ケースは，潮どまりの状況に対応し，堤頂部で射流が発 生しフルード数が1を超えている. 下流水位が上流に伝 わることはなく, 潮止堰上流は低下背水曲線となる.

一方，上げ潮を考慮したケースでは，計算直後は越流 部で射流が発生するが，すぐに常流へと遷移する。この 結果，下流側の水位上昇が上流側へと伝わり，全体的に 水位上昇が進む. なお，この射流から常流への遷移は， 上げ潮流速を半分に弱めた $0.2 \mathrm{~m} / \mathrm{s}$ 解析条件でも生じる ことを確認しており，微弱な上げ潮流でもこのようなダ イナミックな遷移をもたらす可能性を示している.

現地調查で明らかになった潮止堰周囲の状況も今回の 解析結果と一致している. 図-7(k)の写真に写るコンクリ 一ト壁上部の雑草の付着が，潮止堰前後でほぼ同じ高さ で水平に流れている.このことは少なくともピーク水位 時に水位が短距離で急落するような状況が生じていない ことを示唆している.したがって, 潮止堰は平水時には 潮汐を遮断する役割を担うが，洪水時には堰を乗り越え て感潮域が上流に延伸する可能性がある。

表-1 検討条件

\begin{tabular}{|c|c|}
\hline 項目 & 設定 \\
\hline 計画高水流量 & $13,400 \mathrm{~m}^{3} / \mathrm{s}^{0,7)}$ \\
\hline 平均河床勾配 & 1/1500 6)7 （河口～合流点） \\
\hline 平均川幅 & $800 \mathrm{~m}^{6,7)}$ \\
\hline 等流水深 $h_{0}$ & $5.32 \mathrm{~m}$ \\
\hline 限界水深 $h_{\mathrm{c}}$ & $3.06 \mathrm{~m}$ \\
\hline 川幅（潮止堰地点） & 520m (GoogleEarthで測定) \\
\hline 潮止堰形状 & $\begin{array}{l}\text { 天端幅 } 2 \mathrm{~m}, \quad \text { 高さ } 2.4 \mathrm{~m} \\
\text { (現地調査に基づく概略值) }\end{array}$ \\
\hline 潮止堰越流量 & $\begin{array}{l}25.8 \mathrm{~m}^{3} / \mathrm{s} / \mathrm{m} \\
\text { (計画高水流量を潮止堰地点 } \\
\text { の川幅で除した単位幅流量) }\end{array}$ \\
\hline 流速流入境界に与えた流速 & $0.4 \mathrm{~m} / \mathrm{s}^{17)}$ \\
\hline
\end{tabular}

\section{6. 考察}

ここでは，潮汐の影響についてさらなる評価を行うた め, せき上げ背水による水位上昇量を一次元不等流とし て試算し, 海からの諸影響について考えをまとめる.

\section{（1） せき上げ背水の解析的試算}

潮汐は洪水時には潮止堰を乗り越えて上流側の河川水 位に影響を及ぼす可能性がある。しかし，今回行った数 值解析は潮止堰前後の狭い領域を対象とし，計画高水流 量を想定したため, 2018年豪雨時に潮汐が原因で真備町 など上流側でどの程度のせき上げが生じたか，具体的に 示すには至らなかった。

この関係を解き明か寸ためには，広い流域で水理・水 文と潮汐遡上を連成的に解いて, 洪水波と潮汐波の時間 的推移を追いかける必要がある。.また，河川流と潮汐流 の干渉は非常に非線形性の強い現象であり，河口形状に 応じて潮汐の増幅や減衰が生じる ${ }^{18)}$ 19)。正確な予測には, 乱流モデルを組み込み, 淡水, 海水, 空気からなる混相 流を考慮できるモデルによる検討が必要になり容易では ないが，今後の課題としたい.

諸々の制限はあるが，背水の現象を最も単純化すると 広幅長方形断面水路の問題になり, 以下の運動方程式と 連続式を解くことで求めることができる.

$$
\begin{gathered}
\frac{d}{d x}\left(\frac{v^{2}}{2 g}\right)+\frac{d h}{d x}+I-\left(\frac{n^{2} v^{2}}{h^{\frac{4}{3}}}\right)=0 \\
q=h v
\end{gathered}
$$

ここで, $h$ は水深, $q$ は単位幅流量, $v$ は断面平均流速, Iは水路勾配，nはマニングの係数である.この解を求め るためには水深に関して境界条件が一つ必要であるが, 流れが常流ならば下流端で，射流ならば上流端で与える。 高梁川の場合, 計画高水流量でも水路は緩勾配の常流 (等流水深 $>$ 限界水深) であり，下流端に境界を与える ことで求まる．不等流水面形はせき上げ背水曲線（M1 曲線）を描くため，上流側で水位上昇が予想される.

表-1に示した高梁川の諸条件に対寸る計算例として, 上式の第3次近似解 ${ }^{20)}$ を用いて, 水面形の概略を推定し た結果を図-10に示す。下流境界には，高梁川河口の潮 位として1〜3mを入力した. 上流では水面形は等流水深 に一致するが，河口付近では顕著なせき上げが生じる.

等流水深を越える部分をせき上げ背水面とすると，そ

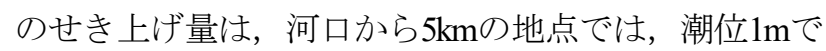

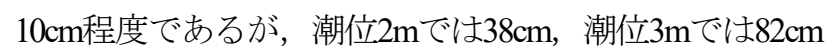
にも達する. 


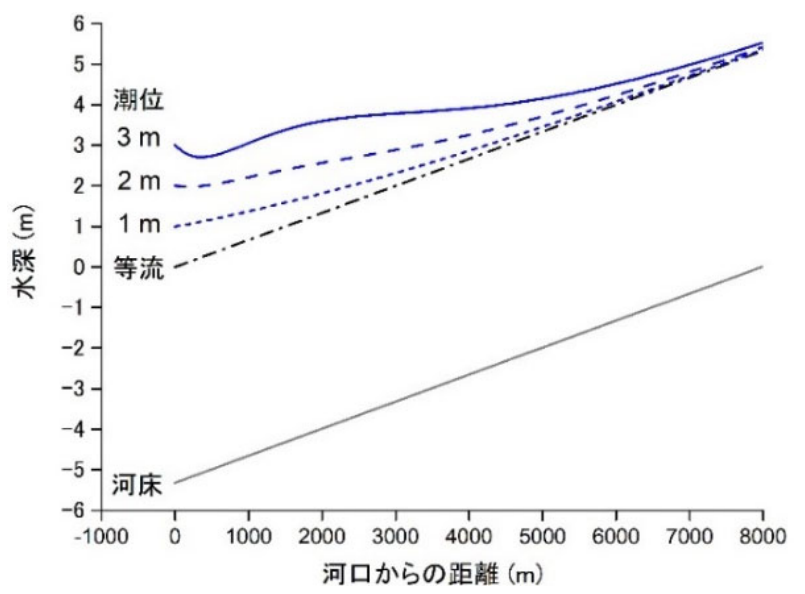

図-10 せき上げ背水曲線の計算例

このように潮位が高くなるにつれてせき上げが大きく なるのは，式(1)が示寸非線形性のためである．同様に， 潮位が高いと下流端での水位拘束条件が強く働き，水面 形に波状が現れる.

したがって，特に瀬戸内海中央部のように日潮差が大 きい場所では，潮汐起因のせき上げで，河口から少なく とも数 $\mathrm{km} の$ 範囲でせき上げの影響が現れると考える必 要がある．高梁川の場合，河口部の川幅は広いが，小田 川との合流地点は狭窄部になっているため，なおさら水 位が上昇しやすい条件にある。

水位ピークが上げ潮の時間帯に一致することで，水位 上昇が助長される可能性もある．例えば酒津の避難判断 水位はT.P.+11.6mであり, 汇濫危険水位のT.P.+12.0mまで $40 \mathrm{~cm}$ の猶予しかない，この間の水位上昇速度は，上げ 潮に重なればさらに急速になるかもしれない，当然この 違いが避難時間の猶予に直結する.

\section{（2）河川水位への海からの諸影響}

以上の結果を踏まえると河川への海からの影響として, 少なくとも以下のような要因を挙げることができる.

(a) 潮汐波の直接の伝播・遡上

（b）河口水位上昇に伴う河川水位勾配の低下と流量 の減少

(c) 河口水位上昇に伴うせき上げ背水面の形成

（d）上げ潮など流下阻害要因が引き起こす堰越流状 態の遷移（射流加常流一）

（e）潜り越流や不完全越流がもたらす下流側水位の 上流側水位一の部分的影響

国土交通省の危険水位及び汇濫危険水位の設定要領 ${ }^{21)}$ では「水位上昇速度については，近年の主要な洪水や河 川整備計画の策定に用いたハイドロ等のうち，高水位部 分の上昇速度が最も速いものを用いて設定する等，個々 の河川の出水特性等を考慮して安全側で設定するものと する」とあり，水位上昇速度について明記されている.
一方，潮汐の影響は，同感潮区間の取り扱いの中で, 「感潮区間における箇所毎の危険水位から洪水予報観測 所での水位への換算にあたり，一定の精度が確保できな い場合は，洪水予報観測所以外の，危険水位を設定した 箇所近傍の観測所で危険水位換算水位を定めるとともに, この水位情報についても提供に努めるものとする」とあ り，潮汐の影響を考慮しているともとれるが，明示的で はない，今回の検討結果が示すように，潮止堰が設置さ れていたとしても，洪水時には感潮区間が上流側に延伸 する可能性があるため，平水時の感潮区間を基準にする と洪水予報に誤差をもたらす恐れがある.

このため，水位の上昇ピークが上げ潮のタイミングに 一致するときには，警報や避難指示により迅速な対応が 求められる，例えば，台風時の気象予報や報道では，満 潮時刻と重なる場合，特別に注意を促すような場面が一 般的になってきた．同様に，河川洪水においても，上げ 潮に一致し，悪条件が予想される場合，より迅速に避難 を喚起するような予報・警報のあり方が検討されるべき と考える. 洪水時であっても河口水位は天文潮位が支配 的であるため, 潮汐条件を数時間前の避難判断に加味す ることは少なくとも論理的には可能である.

\section{7. 結論}

高梁川河口には潮止垵が設置されており，平水時は越 流で生じる射流のため潮汐の影響が上流に及ぶことはな い. しかし，2018年豪雨の後に実施した現地調査では, 最高水位は潮止堰を大きく越え，その前後の水位はほほ 一定で，射流が示寸水位の急変は生じていないことがわ かった．また，河川流と上げ潮の干渉を簡易的に考慮し た数值解析でも，潮止堰付近の流れが短時間で射流から 常流に遷移し，下流側の水位が上流側に伝わることが示 された。すなわち，洪水時には感潮域が上流に延伸する 可能性がある.ささらに，河川水位ピークと上げ潮のタイ ミングが一致していたことや，瀬戸内海でも特に日潮差 が大きい場所であること，近年河口域が著しく広がって いる状況などを総合的に考えると，潮汐が2018年7月豪 雨時の高梁川の河川水位とも関係していた可能性がある.

潮汐は河川水位の上昇を助長・加速する可能性がある。 特に避難判断水位と汇濫危険水位の差が小さいような河 川では，住民の避難猶予時間に少なからず影響を及ぼす 懸念がある，台風時には高潮偏差が加わり，せき上げ背 水がさらに顕著化する可能性もある。このような点も含 めて，河川洪水に及ぼす海からの諸影響について一層の 検証・考慮が必要と考える.

謝辞 : 本研究は科研費(16KK0121 : 研究代表者高木泰士) の支援を受けて行われたことを記す。 


\section{参考文献}

1) 気象庁: 平成 30 年 7 月豪雨（前線及び台風第 7 号に よる大雨等），平成 30 年 7 月 13 日， 2018 .

2) 消防庁: 平成 30 年 7 月豪雨による被害状況及び消防 機関等の対応状況について（第 58 報），2018.

3)内田和子：岡山県小田川流域における水害予防組合 の活動, 水利科学, No. 320, pp. 40-55, 2011.

4) 毎日新聞 : 2018 年 7 月 11 日(水)朝刊, 2018 .

5) 山陽新聞 : 2018 年 7 月 15 日(日)朝刊, 2018 .

6) 国土交通省：高梁川水系河川整備計画（変更）, $134 p ., 2017$.

7) 国土交通省 : 高梁川水系河川整備基本方針（資料 52) , 18 p., 2007.

8) 宇野木早苗 : 河川潮汐の研究 - 第 2 報, 第 16 回海岸 工学講演会講演集, pp. 377-384, 1969.

9) 山口恵一郎ら(編集)：日本図誌大系（中国），朝倉書 店, pp. 140-143, 2018.

10）高木泰士, 富安良一, 荒木健人, 松原恭博, 真野泰 人, 㛜峰, 鈴木正道, 石原一郎, 森勇造, 永瀬翔平, 中村友哉 : 浮上式防潮堤の狭小隙間部から流入する 津波・高潮流量の評価手法，土木学会論文集 B3（海 洋開発），土木学会，Vol. 73, No. 1, pp. 35-42, 2017.

11) Egbert, G. D. and Erofeeva, S. Y.: Efficient inverse modeling of barotropic ocean tides, J. Atmos. Ocean. Technol., Vol. 19, No. 2, pp. 183-204, 2002.
12) 気象庁：平年值（統計期間 1981～2010 年），2011.

13）国土技術研究センター：水文統計ユーティリティー Version 1.5 操作マニュアル, 23p., 2017.

14) 山陽新聞 : 2018 年 7 月 11 日(水)朝刊, 2018 .

15) 岡山県：岡山県地域防災計画（資料編），第 3 章 予 報及び警報等の種類と基準等， 2018 。

16) 宇野木早苗 : 流系の科学, 築地書館, 364p., 2010.

17) 白木喜章, 高尾敏幸, 柴木秀之, 山下義昭, 田中丈 裕：岡山県水島港周辺海域における流況・SS 分布予 測モデルの開発, 海洋開発論文集, 第 24 巻, pp. 1069-1074, 2008.

18) Savenije, H. H. G.: A simple analytical expression to describe tidal damping or amplification, Journal of Hydrology, Vol. 243, pp. 205-215, 2001.

19) Takagi, H., Tran T. V., Nguyen, D. T. and Esteban, M.: Ocean tides and the influence of sea-level rise on floods in urban areas of the Mekong Delta, Journal of Flood Risk Management, Vol. 8, No. 4, pp. 292-300, 2014.

20) 神田徹, 浜村吉昭：広幅長方形断面水路におけるせ き上げ背水曲線の簡略計算式，土木学会論文集，No. 387, pp. 301-304, 1987.

21）国土交通省: 危険水位, 特別警戒水位, 避難判断水 位の設定要領, 2014.

(2018. 8. 6 受付)

\title{
INTERRELATIONSHIP BETWEEN RIVER WATER LEVEL AND OCEANIC TIDE DURING 2018 WESTERN JAPAN FLOODS: FIELD SURVEY AND NUMERICAL ANALYSIS
}

\author{
Hiroshi TAKAGI, Luc HENRY and Takumi MIZUOCHI
}

The historical flood that occurred in western Japan in July 2018 claimed over two hundred lives. The river embankment breach caused severe flood damages particularly in Okayama, leading to complete destruction of 2100 houses. According to the engineers who appeared in the news, the flood was likely triggered by fluvial backwaters between Takahashi and Oda River. To understand whether other mechanisms might have been related to this flood event, we investigated the interconnection between tides in Seto Inland Sea and water levels in Takahashi River. This concern originated from two facts: (1) the river mouth of Takahashi River has been expanded because of the extensive river/port development, and (2) the inner part of Seto Inland Sea is subject to high tides due to the two tidal waves from both sides of the sea. We performed a numerical analysis to simulate the strong turbulence induced by the collision of the flood tide and river flow around a submerged weir constructed near the river mouth. The computational result demonstrates that a moderate tidal flow triggers the phase shift of the hydraulic regime from supercritical to subcritical flow, leading to substantial increase in river water levels. The survey we conducted one month after the disaster confirmed that the flood watermark found adjacent to the weir was not remarkably different between the leeward and windward of the structure, which indicates that a supercritical flow did not occur during the flood peak. A hydrological analysis reveals that the timing of peak water levels during the 2018 flood corresponded to the phase of the flood tide. Thus, it is likely that the upstream water level excessively rose because the flood tide seemed to disturb the river outflow. The study findings suggest that the phase of estuary tides should also be considered for river flood risk management. 